\title{
Internationalization and the Structure of the Company's Marketing Strategy on International Markets-Theoretical Remarks
}

\author{
Jan Władysław Wiktor \\ Cracow University of Economics, Cracow, Poland
}

\begin{abstract}
The paper presents theoretical reflection upon international marketing strategy in the framework of internationalization and globalization of the market. It consists of four parts. The first one debates the nature and reasons for corporate internationalization. The second part shows an international marketing strategy in the concept of corporate expansion. The strategy consists of two elements: the basic dimensions of foreign market entry modes (part 3) and business presence strategies in overseas markets (part 4). This paper proposes a theoretical framework for research conducted by Department of Marketing of the Cracow University of Economics. The research has been conducted as a part of grant received by Polish National Centre of Science.
\end{abstract}

Key words: corporate internationalization, international marketing strategy, foreign market entry modes, strategies in dealing with overseas markets

\section{Introduction}

Internationalization is an increasingly common and significant phenomenon of the contemporary economy. The various forms of international economic cooperation between countries and enterprises, especially transnational corporations, constitute the spectacular signum temporis of the economy of today's world-a global market or a global village. Such a situation results from the liberalization and deregulation of national economies, reflecting the openness to the external world and engagement in the international and global market, as well as from the on-going global internationalization processes and the establishment of great transnational groups including the EU (European Union), NAFTA (North American Free Trade Agreement), ASEAN (Association of South-East Asian Nations), MERCOSUR (Mercado Comun del Cono Sur), APEC (Asia-Pacific Economic Cooperation), BRICS (Brazil, Russia, India, China, South Africa), and Next-11. Internationalization gives rise to international marketing (and its development) —a peculiar "art" and skill and a "philosophy" of corporate activities in an increasingly complex and multidimensional environment of international and global markets. Internationalization processes and companies' decisions to internationalize their activities lead to applying specific solutions with regard to entry and long-term strategies adopted on overseas markets. Such decisions determine the marketing activities of companies focusing on overseas

\footnotetext{
Jan Władysław Wiktor, Ph.D., professor, Department of Marketing, Cracow University of Economics, Cracow, Poland.

Correspondence concerning the economics aspects of this article may be addressed to Jan Władysław Wiktor, Cracow University of Economics, 31-510, ul. Rakowicka 27, Cracow, Poland. E-mail: jan.wiktor@uek.krakow.pl.
} 
operations, as well as the various forms of cooperation and competition at the international and global level. This approach to an analysis of the concept of international marketing, its essence and characteristics is adopted in the second part of the monograph. The essence of internationalization as a phenomenon and a process is discussed at the country and company level.

At the level of the country, internationalization indicates the opening of an economic system to the world and international exchange as well as an increase in the economic links between the particular countries and their greater engagement in the international division of labour. In this approach, internationalization is an area of analyses, studies, and research undertaken by the theory of international economics, especially its subsystems: macroeconomics (an open economy), international economic relations, and international trade. Therefore, it is mainly a macroeconomic concept.

Simultaneously, internationalization is one of the major areas of microeconomic considerations - the theory of the firm and development, management and marketing strategies. It is at the microeconomic level that the concept of internationalization is filled with specific content of dual character.

On one hand, internationalization indicates any form of corporate activity undertaken outside the home country, regardless of the amount of engaged resources (Harrison, Dalkiran, \& Elsey, 2000; Rymarczyk, 2004; Keegan \& Green, 2011). Internationalization is not passive - it is a specific and complex phenomenon and a process aimed to internationalize the company's market of its business activities. It should be viewed in its dynamic and active dimension - at the retrospective level (previously established and presently continued international links) as well as from the point of view of the company's prospective development trends.

On the other hand, internationalization should be viewed in a broader sense-it manifests itself in the "company's internationalization" on the domestic market through its cooperation with foreign partners in the form of the supply of materials (import), the performance of the function of a sales representative and agent who develops overseas distribution channels on a given local market for the needs of a transnational corporation, the purchase of licences, consultancy services, cooperation exports, etc.. In such business conditions, a domestic company becomes part of international operations without leaving the domestic market; it deals with different products and production techniques and technologies, a different organizational culture, a different approach to setting objectives, developing strategies and creating conditions for cooperation with foreign partners. Consequently, internationalization at this level results from the strategic analysis which identifies the company's strengths and weaknesses as well as external opportunities and threats, leading to the decision to engage - to varying degrees and in different manners - in international operations.

Internationalization originates from specific political, social, economic, technical, and technological factors. These factors, in the context of the reasons for globalization (Yip, 2004), are divided into five groups related to markets, costs, governments, competition, and additional factors.

The major or "initial" factors which affect the company's international orientation include political and legal conditions. They are given much attention in literatures, so it is not necessary to discuss their characteristics in this monograph. In should be noted, however, that the value chain offered by contemporary international companies is more extensive and complex in terms of the volume of goods and services as well as the degree of their functional attractiveness. The development of product offerings that would facilitate gaining and retaining competitive advantage at the international and global level requires closer cooperation between companies and states. The on-going processes of corporate technical, organizational, and capital concentration 
are the significant drivers of internationalization and companies' efforts to undertake different forms of activity on international markets.

The continuous technological advancement leads to increased production outputs at the international and global levels. Undoubtedly, new opportunities result from increased R\&D expenditures, but they also stimulate their growth. It encourages transnational corporations as well as "national" companies to set up strategic alliances and to tighten international cooperation. It is required by the development of science, research, and technologies. The globally increased production effectiveness leads to corporate international expansion including companies' presence on the global market. It reflects companies' natural and understandable expectations with regard to the liberalization of conditions for operating on international markets. Such liberalization is a prerequisite for market expansion, discounted investment outlays in R\&D activities and for achieving real economic growth. Rapid advancements in science and technology and the implementation of R\&D achievements lead to a number of consequences. They give the existing systems a new dimension and create new industries and economic sectors on the basis of the global communication network (the internet), facilitate the unprecedented business communication opportunities, and create new global consumers and new needs and, consequently, different ways of satisfying them. As a result, they support internationalization processes at the level of the particular countries, their economic systems, and companies.

Internationalization processes not only originate from, but also result in globalization processes. Globalization, in its broadest sense, indicates the intensification of political, cultural, and economic relations at an international level. It is a process of tightening mutual relations among countries, groups of countries, their economies and enterprises (Ball \& McCulloch 1999; Zorska, 2000; Stonehouse, Hamill, Campbell, \& Purdie, 2001; Liberska, 2002; Stieglitz, 2011). At the level of economics and management, globalization is a complex and dynamic process of increasing production output and the exchange of goods, services, and capital on an international scale. It extends the degree of internationalization of national economies, leading to the penetration and convergence of markets on which companies carry out their operations. Openness is a fundamental characteristic of the contemporary markets of goods, services, labour, and capital in an increasing number of countries, especially highly advanced economies.

Globalization factors stimulate the liberalization of foreign trade and internationalization of production and distribution, they shorten the life cycles of an increasing number of goods and services, and increase R\&D expenses and the total spending on technology development, especially in IT and telecommunications, transforming the world into a "global village". Globalization is discussed from this perspective by McGrew and Lewis (1996, p. 50) who state that globalization refers to numerous links between nations and communities which create the current system of the world. It describes a process in which events, decisions, and activities in one part of the world have a major impact on the individuals and entire communities in the remote regions of the globe. On one hand, the term "globalization" describes a number of processes which take place worldwide. This concept, then, has a spatial dimension. On the other hand, it implies a greater number of links and interdependencies in mutual relations between the countries and societies which create the global community (Grupa, 1996, p. 50; Lesáková, 2000; Baláž, 2001).

Globalization, the fundamental mega-trend in the development of the contemporary world, is a complex and multidimensional phenomenon. It covers most of, or practically all areas of social, cultural, political, and economic activity, extending beyond the territory of a given country, its society and economy. Globalization 
processes refer to markets, corporate functioning strategies, finance, technologies, research and development, knowledge, life styles, consumption models, access to culture, management styles, and legal regulations.

Internationalization and globalization processes relate to specific types of companies-transnational corporations (international, multinational, and global enterprises). They should be viewed in two dimensions: firstly, as the drivers of internationalization and globalization processes; and secondly, as the effects of such processes. Undoubtedly, the drivers of corporate expansion and strategies for entering into foreign markets stimulate the process of economic liberalization and deregulation at an international level. On the other hand, the rapid development of transnational corporations results from breakthrough changes in their international and global environment. Such changes are reflected in the removal of barriers to communication and the transfer of capital, new technologies as well as the results of research and development projects. Such conditions provide unprecedented opportunities for carrying out activities from large distances (at the international and global level), enabling corporations to access new markets and industries.

\section{An International Marketing Strategy in the Concept of Corporate Expansion}

An international marketing strategy is part of the general concept of corporate functioning and expansion. The company's strategy represents its long-term development, while an international marketing strategy reflects the specific dimensions of the company's international orientation resulting from the particular causes and motives of internationalization.

An expansion strategy is a set of relatively well-established principles of corporate functioning aimed to achieve the main objectives defined in the company's mission statement. Those principles also set a framework for company market activities and, as part of this framework, identify the scope of possible and acceptable strategic and operational solutions (Stabryła, 2000; Schlegelmilch, 2001; Obłój, 2002; Żabiński, 2002; Pierścionek, 2003; Bradley, 2005; Urbanowska-Sojkin, Banaszyk, \& Witczak, 2007; Obłój \& Wąsowska, 2014).

Strategic decisions are based on the company's mission - the most general description of company goals, plans, and principles of marketing activities. A mission statement reflects "a specific reason for the company's existence" as well as its core activity (presently and in the future). It identifies the company's area of market activities at the level of products and markets. A contemporary approach to corporate missions stresses the market-related aspect of core activities: Customers and their needs, a selected target market and the ways in which customer needs are satisfied. Mission statements formulated by transnational companies place an increasing emphasis on the international character of their business operations (Backhaus, Büschken, \& Voeth 2001; Cardona \& Rey, 2009; Czubała, 2012). The company's strategy reflects the ways in which it considers its future activities - development trends as well as mid- and long-term functioning principles. It can be regarded as "a road map" which describes the ways of reaching company objectives. An international marketing strategy is part of that description-it describes the way in which the company engages in international market operations and responds to challenges posed by internationalization and globalization processes.

An international marketing strategy is part of the company's general strategy. It is based on the same principles as those applied in developing a general concept of corporate expansion. This issue is widely discussed in literatures and does not require further attention in this papers (Ďad'o, 1997; Harrison et al., 2000; Czinkota \& Ronkainen, 2004; Wiktor, Oczkowska, \& Żbikowska, 2008; Nowakowski, 2008; Duliniec, 2009; Grzegorczyk, 2009; Hollensen, 2011; Kotler \& Keller, 2012; Wiktor \& Chlipała, 2012). 
However, it should be stressed that international marketing strategies should be viewed in a broader perspective and the following factors should be considered:

- the company's general development strategy;

- a set of external conditions generated by the domestic and international environment which engages companies in internationalization processes through specific proactive and reactive factors;

- the company's marketing strategy.

The above factors are mutually interlinked. An international marketing strategy is not a fully independent vision for corporate development, but an instrument for achieving the objectives which are described in the company's mission as well as in the general development concepts and patterns which constitute a strategy for business operations on domestic (internal) and international or global markets.

The character of an international marketing strategy is determined by the specific motives of corporate internationalization (Proctor, 1996; Nowakowski, 2000; Kotler, Armstrong, Saunders, \& Wong, 2002; Gorynia, 2007; Fonfara, 2009). The decisions to go international and enter into overseas markets are conditioned by a number of variables, falling under two basic categories:

- endogenous variables - company characteristics;

- exogenous variables - external factors.

The endogenous variables are determined by the company's available resources, its objectives, and offered values - the marketing mix (4P, 5P, 4C). Such factors are of fundamental significance. They represent company assets, tangible, and financial property as well as the efficient use of the available resources reflected in the ratios related to the company's market value, dividend payments, return on capital, return on equity, profitability, rentability, etc.. Also, the internal factors include human resources, the volume and structure of the intellectual capital, the company's knowledge management system, the assets related to the company's market position (reflecting its strengths in the macro- and microeconomic context), and the company's opportunities and threats in different time horizons. Apart from the intellectual capital and knowledge management systems, marketing assets reflect the knowledge of local markets, business experience, the company's ability to take effective action as well as the knowledge about the management and marketing methods and instruments applied in the contemporary turbulent economic environment.

The company's assets comprise a set of all the components that create its market value and co-create its competitive position. Those assets, viewed in their absolute and relative dimension, determine the company's development trends, including decisions to enter into international markets. Such decisions require the engagement of resources which, especially in the initial period of international expansion, are treated as (relatively) fixed costs.

The exogenous variables are the components of the domestic and foreign environment (in the target country of business expansion).

In both dimensions, the reasons for and conditions of the decision to enter into international markets refer to the impact of the particular macro- and micro-economic factors. Apart from a given structure of the market and the concentration of competition, a special role at this stage of the analysis and the presented considerations is played by the character of the macroeconomic environment in the country (countries) of prospective corporate expansion. In this context, two factors play a decisive role:

- quality differences as compared with the home market which result from to a number of factors which create the demographic, economic, political, legal, natural, and cultural environment; 
- characteristics of the potential impact - the macroeconomic environment of the target country can have a positive or adverse impact on the company's intended activities. It can offer short- and long-term opportunities, or pose some threats. The evaluation of such factors and the ways in which they translate into entry decisions provide opportunities for a further analysis of the problems of the international environment.

Dietl (2005) rightly stated that the business market environment as a concept is being redefined. Corporate internationalization and globalization also affect small and medium enterprises. The classification of marketing into international and home activities is not adequate any more. Marketing decisions may hardly be taken without considering the realities of globalization processes. Space conversion and compression reduce the role of the location of company operations. Even from the perspective of small companies, the territory of business operations becomes considerably larger along with the structure of target markets as a result of closer links between substitute and complementary goods. The territorial scope of collecting information, a basis for marketing decisions, is also expanding (Dietl, 2005; Kita, 2000).
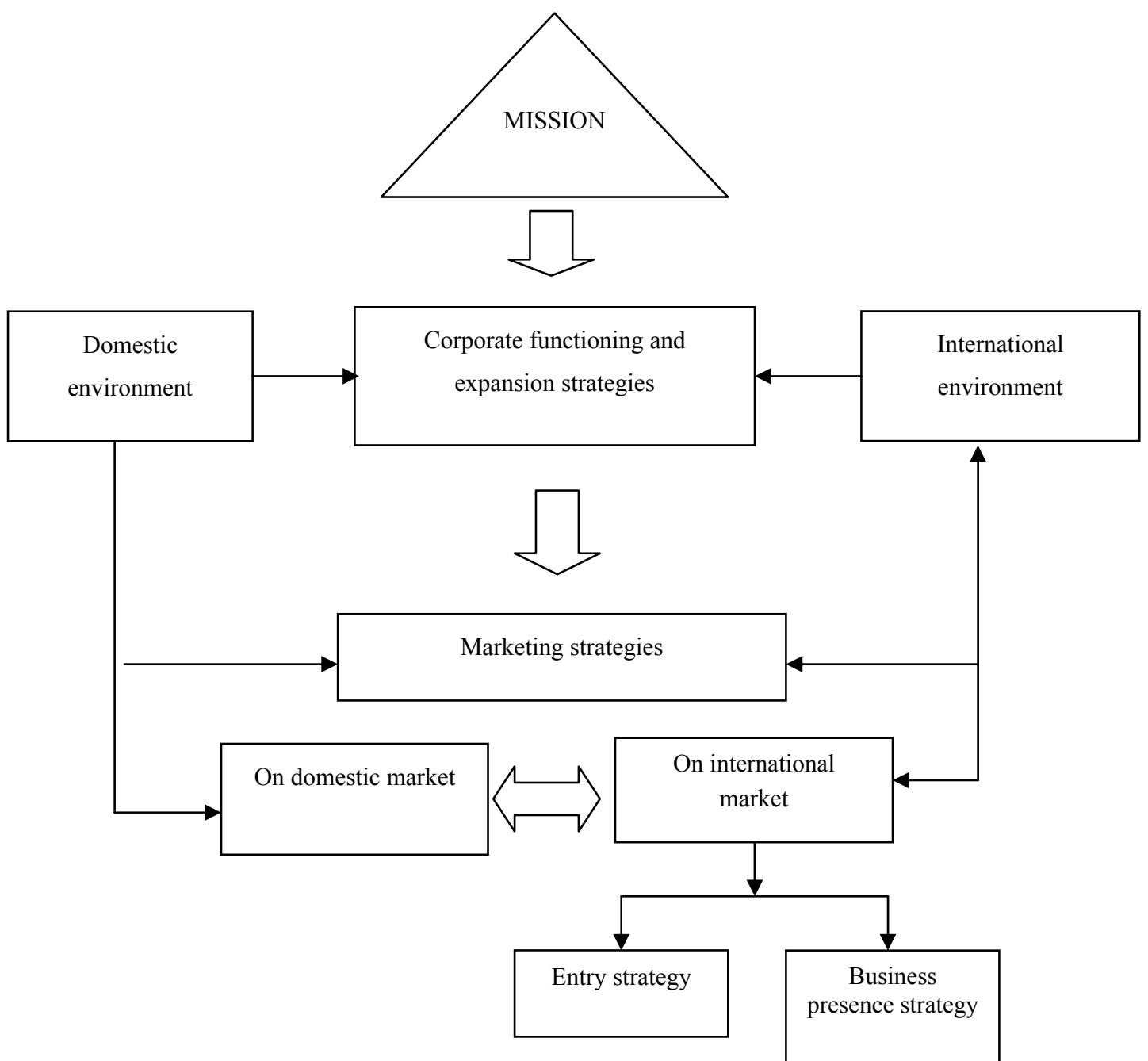

Figure 1. International marketing strategy in the context of general corporate functioning and expansion strategy. Source: author's research

The decision to internationalize corporate activities results in developing an international marketing strategy based on two fundamental decision-related areas and components which may be referred to as: 
- a foreign market entry mode;

- a business presence strategy on foreign markets (a set of principles and a general approach to marketing services and marketing "processing") shown in Figure 1.

\section{Basic Dimensions of Foreign Market Entry Modes}

The character and development of a strategy for entering overseas markets are the immediate effects of the company's internationalization strategy. Such strategies are usually described through identifying specific methods and forms of market expansion. Literatures offer different classifications of entry modes based on a number of criteria. The basic criteria include the scope of the transfer of capital to foreign markets, the costs of entry, risk, the identification of opportunities, etc., for example, Meissner (1981) and Berekoven (1985) treated entries into overseas markets as a process and proposed a gradual model for implementing internationalization - its initial phase is based on simple forms (foreign trade), followed by more complex undertakings (joint ventures), and finally reaching the stage of setting up a new company abroad (also see: Hermanns \& Wissmeier, 1995; Mühlbacher, Dahringer, \& Leits, 1999; Jaint, 2001; Schlegelmilch, 2001).

The above proposal, considered to be one of the major ones proposed in literatures, can be considered here as one of the possible foreign market entry modes. The particular strategies, apart from being clearly distinctive in terms of their organizational, economic, and legal substance, are not mutually exclusive, and their time sequence is not pre-determined. Any possible method which reflects a different scope of the transfer of capital to foreign markets is appropriate in a given market configuration, being applicable to both domestic and overseas markets. It is also the "function of the company's experience", the identification of "unexpected" opportunities, or a subjective assessment of risk. In the light of the above factors, the choice of more complex forms of operations does not require the use of simple strategies and activities which are characteristics of the initial phases of internationalization.

A different and interesting classification of the modes of internationalization is proposed by Kulhavy (1990), who regarded the location of production to be a major typology criterion. He distinguished two basic groups of foreign market entry modes determined by the following:

- production activities on the domestic market;

- production activities on foreign markets.

Kulhavy's concept can be slightly modified by adding the criterion of the involvement of capital on foreign markets; consequently, four groups of entry modes can be proposed:

- strategies based on domestic production without foreign investments (indirect and direct export with the use of foreign distribution channels);

- strategies based on domestic production and investment engagement on foreign markets (direct export based on the company's own distribution channels);

- strategies based on production on foreign markets without investment projects (the sale of licences, franchising, management and other contracts);

- strategies based on production on foreign markets and investment projects (joint ventures and the company's own facilities).

The above approaches are significant from a cognitive point of view, but it seems that they are not comprehensive in character. A broad and comprehensive entry strategy should consider all possible strategic dimensions including the following: 
- market areas of company operations;

- scope of the territory of activities;

- economic and financial aspects;

- organizational factors;

- time framework.

Obviously, all these dimensions refer to different business areas; however, they are closely related, and it is the combination of different factors that conditions a comprehensive analysis of the relevant factors.

The market areas of company operations reflect the company's core activities viewed from the perspective of products and markets. The possibilities for shaping market areas and making strategic choices are offered by Ansoff's matrix. All the proposed strategic development options, except for the market penetration option, i.e. product development, market development, and diversification, offer opportunities for developing a strategy for business operations on a foreign market and engaging a company in international marketing activities. Obviously, the specific decisions are affected by the above discussed internal and external conditions.

The strategic option of the territorial scope of the market offers a fairly detailed description of corporate expansion opportunities on foreign markets. The description of the company's market, defined in its objective and subjective dimension, should also include its geographical aspects. Markets should possess their territorial "borders". In this context, apart from strategies for business operations carried out exclusively on the domestic market, a significant role is played by seeking development trends focusing on internationalization and international market strategies (including global strategies). Entry into new markets (foreign markets) may be based on different modes referred to literatures as the mode of "concentration", the "selective" mode, and the mode of "island".

The economic and financial dimension of internationalization strategies, including entry modes, is determined by two basic factors. The first one refers to the allocation of resources - their adaptation to international activities. It involves the higher levels of investment outlays (fixed costs), especially in the initial phase of entering into the market, as well as the variable costs resulting from market entry and business presence modes and the scope of business operations. Corporate entry strategies require specific investment outlays. The second factor is related to the share of revenues resulting from the sale of goods and services on a foreign market. The proportion between domestic and foreign market revenues may vary depending on the adopted internationalization strategy. It always reflects the company's engagement in foreign market operations and the effectiveness of its overseas marketing activities. The company's performance on foreign markets (sales and profitability) stimulates its further expansion.

The organizational dimension of a foreign market entry strategy relates to offering answers to the questions concerning the number of markets being simultaneously targeted, or the possible order of entries in the event of gradual expansion. It translates the strategic decisions concerning the territorial scope of the market and transnational market options into specific activities. The answers to the above questions are referred to in literatures as waterfall, sprinkler, and mixed strategies (Hünerberg, 1994).

Timing is a significant component of entry strategies. A strategy, by its very nature, is a dynamic concept - it expresses the desirable trend of changes in the company's subsystems and functioning principles in the course of time. It also applies to foreign market entry strategies, because corporate expansion into foreign markets is a complex short- or long-term process.

An entry strategy is usually viewed as the consequence of the internationalization process, which 
Berekoven divided into four stages: a preliminary stage, an introductory stage, a stage of increased interest in internationalization, and a stage of mature internationalization. The last two stages are characterised by the transfer of considerably greater volumes of production output to foreign markets. Consequently, foreign markets perform a major function in company operations as the main target for the allocation of resources, the basic source of generating revenues and profits, and the main place for carrying out marketing activities.

The gradual processes of entering into foreign markets involve a strategy for getting acquainted with the international environment and international markets described by the Uppsala model. However, it is not the only model for analysing the timing of an entry strategy. Apart from the gradual model, market entry strategies may rely on the born-global model. It has a completely different character-the company is deprived of the possibility of getting acquainted with the markets of the particular countries or continents, but it strives to retain its presence on the global market from the very beginning of its business operations. The entry of "born global" companies into world markets does not result from their willingness to strengthen the position on the domestic market, but from the decision to be present on global markets as well as from the "the spirit" of global entrepreneurship represented by company owners and executives. The reasons for such strategies and a considerable reduction in the periods of overseas expansion lead to market globalization processes and the resulting possibility for standardised offerings and their acceptance by global consumer segments. Thus, internationalization is a major factor which distinguishes the marketing strategies adopted by "born global" companies. Such companies represent the world's modern industries including electronics, IT, and telecommunications, which play a special role in setting global standards for products and related services. Making use of the concept of the network company, they offer global value chains based on the internet-a global communication and information exchange network.

The internationalization process is also a challenge posed by the contemporary business world to stimulate cooperation — upon the entry and at later stages—-based on a network approach. Fonfara's team members relied their research project on this approach in 2009.

Literatures offer a number of classifications of entry strategies based on various criteria (Meissner, 1981; Berekoven, 1985). Slightly different strategic aspects of entry modes are discussed by Sznajder (1992) and Gorynia (2007). The basic criteria include factors such as the transfer of capital to foreign markets, the costs of entry, risk, an assessment of opportunities and threats in the international environment, etc.. The group of possible strategies includes basic modes (export), "indirect" ones (the sale of licences abroad, franchising and joint ventures) as well as more complex forms - establishing new entities on foreign markets (branches, plants, and fully independent daughter companies).

All classifications give priority to export as a major corporate strategy for expanding into foreign markets. This strategy performs a unique function. Export is a basis for internationalization — not merely a preliminary and initial stage of the company's international activities and its engagement in international trade. It constitutes a platform for the advanced level of internationalizing the corporations which apply more complex modes of entry - joint ventures or direct foreign investment, making their new locations a starting point for further expansion based on export. ${ }^{1}$ Corporate entry strategies may be implemented on the basis of direct and indirect

\footnotetext{
${ }^{1}$ It is practiced by transnational corporations upon their entry into the Polish market, which, benefiting from their presence in the EU, export their products to other EU member states, for example, FIAT had manufactured 2,000,000 "pandas" in its Tychy-Poland, facility by 2010 , exporting vehicles to 67 countries worldwide.
} 
export as well as by an additional mode of export—cooperation-based export (Chlipała \& Żbikowska, 2010).

Indirect export is based on the sale of products to an agent-a domestic exporter or a foreign importer, with a view to reselling these products on foreign markets. Agency functions may be performed by domestic companies focusing on overseas operations, representing various formal, legal and functional forms of activity: trading agencies, foreign trade enterprises and societies, specialised wholesalers, foreign importers' subsidiaries, etc.. It is also possible to rely on the experience, international connections, and distribution channels of other domestic manufacturers (Żbikowska, 2012). This strategy is referred to as piggybacking. Agents may act as independent buyers who conclude their own transactions or as consignees. The actual level of internationalization based on indirect export is not high. It results from a number of factors, especially from the absence of contacts established by exporters with foreign markets, their environment, agents, and clients in the target country. The exporting company is not obliged to be acquainted with border crossing procedures, foreign trade methods, and techniques or detailed principles of international marketing. In practice, the only contacts with overseas markets are necessitated by foreign buyers' requirements in the course of developing product marketing characteristics and adapting to buyers' needs and requirements according to the "actual" exporter's recommendations. A product packaging with foreign language descriptions and symbols required by agents and target markets may serve as an example.

Indirect export is a mode of corporate internalization adopted by entities which lack foreign trade experience and which are not acquainted with a given market as well as those which do not engage in a large number of transactions (one-time contracts) and whose marketing and financial conditions do not facilitate independent overseas activities. Consequently, an indirect exporter does not incur the costs resulting from international marketing activities: market research, overseas promotion campaigns, distribution (transport, warehousing), etc.. For these reasons, indirect export is a favourable mode of entering into foreign markets for small and medium-sized entities which lack international business experience. It may also be applied by large companies in the event of decreasing or strongly fluctuating demand on overseas markets, companies' lack of expertise, and their fear of potential risk resulting from international activities.

The basic benefits of indirect export are attributed to the transfer of transactional risk from the manufacturing company to the exporting agent. However, such benefits are relative in character. Exporters deprive themselves of direct contacts with a foreign market; as a result, they do not exercise control over the mode of sales, the level of prices, and promotion policies. Moreover, they are not in a position to identify the needs and preferences of foreign agents and consumers, who view the exporting company as an anonymous entity.

The negative aspects of indirect export concern less than direct export. This mode of export eliminates domestic agents (who act as the actual exporters), making the company undertake all classical foreign trade activities: market research, the choice of buyers in the target country, establishing contacts, carrying out trade negotiations, concluding contracts, preparing documentation, organizing the physical distribution of goods, etc.. Direct export provides the possibility of establishing contacts with the particular clients: agents, wholesalers, and retailers, as well as shaping the selected market segment in accordance with the exporter's own vision, strategies, and expectations. This mode of internationalization enables the company to create (strengthen or change) its image on the foreign as well as the domestic market. Such benefits, however, are conditioned by substantial outlays including higher organizational costs of export activities, greater expectations as well as responsibility and risk resulting from a market entry in a different cultural, economic, and legal environment. 
The advantages and disadvantages of direct export manifest themselves in different ways, depending on the adopted mode of activities. Direct export may be based on domestic and foreign distribution channels, involving different scopes of potential foreign investment outlays. Foreign channels rely on the sales links and institutions which belong to other market players. The company's own channels, on the other hand, require developing sales networks which are characterised by the above costs and benefits. This mode of export is frequently applied when products require specialised sales methods and promotion campaigns as well as in the event of long-term exports with large transaction volumes.

Cooperation export, in turn, is based on the institutional cooperation of a number of manufacturers during the phase of completing a joint offering of sales on overseas markets, adopting a common entry strategy, followed by implementing the pre-defined business presence strategy approved by the respective parties.

A broader assessment of foreign market entry strategies based on exports requires an analysis of the major dimensions and components of an international marketing strategy. Those dimensions refer to time, organization, finance, and space - the issues discussed in much detail in literatures.

An analysis of export as a mode of corporate internalization should take into account the fact that the particular strategies, apart from their distinct content and organizational, economic, and legal characteristics, are not mutually exclusive, and their time sequence is not pre-determined. Each possible mode reflects a different scope of the transfer of capital to overseas markets and is determined by a specific configuration of the domestic as well as the foreign market. It also represents the company's experience and the identification of possible opportunities or a subjective assessment of risk. In the light of those factors, companies may choose a gradual entry with limited capital engagement, for example through export, or adopt a completely different approach placed on the other side of the linear model - setting up a joint venture, acquiring a company or building a new facility. Another combination is offered by a "mixed" entry. It may be based on reversing the classical linear development strategy. The company enters a foreign market and retains its business presence on a lasting and institutional basis through the construction of its own facility, the start-up of production activities, followed by the export of new products to other markets as part of the concentric, "island" or selective strategy. This solution results from the willingness to overcome customs and non-tariff barriers, which hinder international exchange.

The decision to enter a foreign market is one of the company's most significant strategic undertakings. Its impact results from the company's market focus and its long-term engagement of resources. Specific internationalization decisions are affected by internal as well as external factors (the latter ones beyond the company's control). The obvious consequence of the decision to go international is the choice of a foreign market entry mode. Companies can apply a wide spectrum of strategies and entry modes depending on the necessary engagement of capital, the scope of international experience, risk factors, etc.. The presented typology is a theoretical consideration to be considered by companies which may choose different modes and combinations, enabling them to accomplish their missions and implement their strategies, and to ensure their target positions on international markets in the changing and turbulent environment of the contemporary global economy.

\section{Business Presence Strategies on Overseas Markets}

The other significant factor which impacts corporate strategic undertakings in international marketing is the choice of business presence strategies (modes) on foreign markets. They refer to a broad area of decisions 
and a set of principles related to the adopted approach to international markets, the ways in which they are served, companies' attitude to competition and other fundamental and strategic aspects of corporate international marketing (Table 1).

Business presence strategies can be viewed from different perspectives in terms of their general or specific character. The following strategies are regarded to be fundamental:

- those presenting a general approach to international markets, determined by the standardization-adaptation dilemma;

- those identifying methods for serving ("processing") the market, facilitating the identification of ethnocentric, polycentric, regiocentric, and global strategies (a strategic EPRG model).

In this context, a number of specific business presence strategies may be identified, which represent the company's attitude to its clients, competitors, marketing channel agents, and other groups of stakeholders.

Table 1

Classification of the Basic Dimensions of Business Presence Strategies on International Markets

\begin{tabular}{|l|l|l|l|l|l|}
\hline Description & \multicolumn{3}{|c|}{ Types (components) of business presence strategies } \\
\hline $\begin{array}{l}\text { 1. General approach } \\
\begin{array}{l}\text { 2. Method for serving } \\
\text { (“processing”) the } \\
\text { market-EPRG Model }\end{array}\end{array}$ & Ethnocentric approach & Polycentric approach & Regiocentric approach & Geocentric approach \\
\hline $\begin{array}{l}\text { 2. Competitive strategies: } \\
\text {-Porter (1996) }\end{array}$ & Cost minimization & Differentiation & \multicolumn{2}{|c|}{ Adaptation (individualised approach) } \\
\hline -Obłój (2002) & Launch frontal attack & Conquer the market & Avoid competition & Create a new market \\
\hline $\begin{array}{l}\text { 3. Strategies for serving buyers } \\
\text { (Ohmae, 1982) }\end{array}$ & $\begin{array}{l}\text { Build functional } \\
\text { differentiation }\end{array}$ & \multicolumn{2}{|c|}{ Aggressive initiative } & Relative advantage & $\begin{array}{l}\text { Maximum buyer } \\
\text { satisfaction }\end{array}$ \\
\hline
\end{tabular}

Source: author's research based on Porter (1996), Obłój (2002), and Ohmae (1982).

The above proposals seem to correspond to the general aspects of corporate functioning. Literatures in the field of strategic management and marketing, however, refer to such aspects without giving consideration to their international dimensions.

In the light of the above, a synthetic commentary can be proposed with regard to the basic business presence strategies on international markets (Figure 2).

The basic dimension of a business presence strategy is reflected in the company's general approach to international markets, characterised by the standardization versus adaptation (individualization) option. This issue is widely discussed in literatures, so it does not require special attention in this monograph. It should be stressed, however, that a compromise between the reasons for standardization and adaptation and the related requirements has significant cognitive implications. It determines development opportunities for companies and buyers as well as their business environment on a given national market.

Through their offerings, know-how, product and technical innovations as well as modern management and marketing systems, companies make a significant contribution to the development of foreign markets. On the other hand, expansion on new markets gives companies an opportunity to increase their knowledge of the market, culture, life styles, and the actual consumer behaviour in different social, legal, and economic conditions, and then, as a result of the relevant feedback, companies can use that knowledge in the further development of their international marketing strategies. 


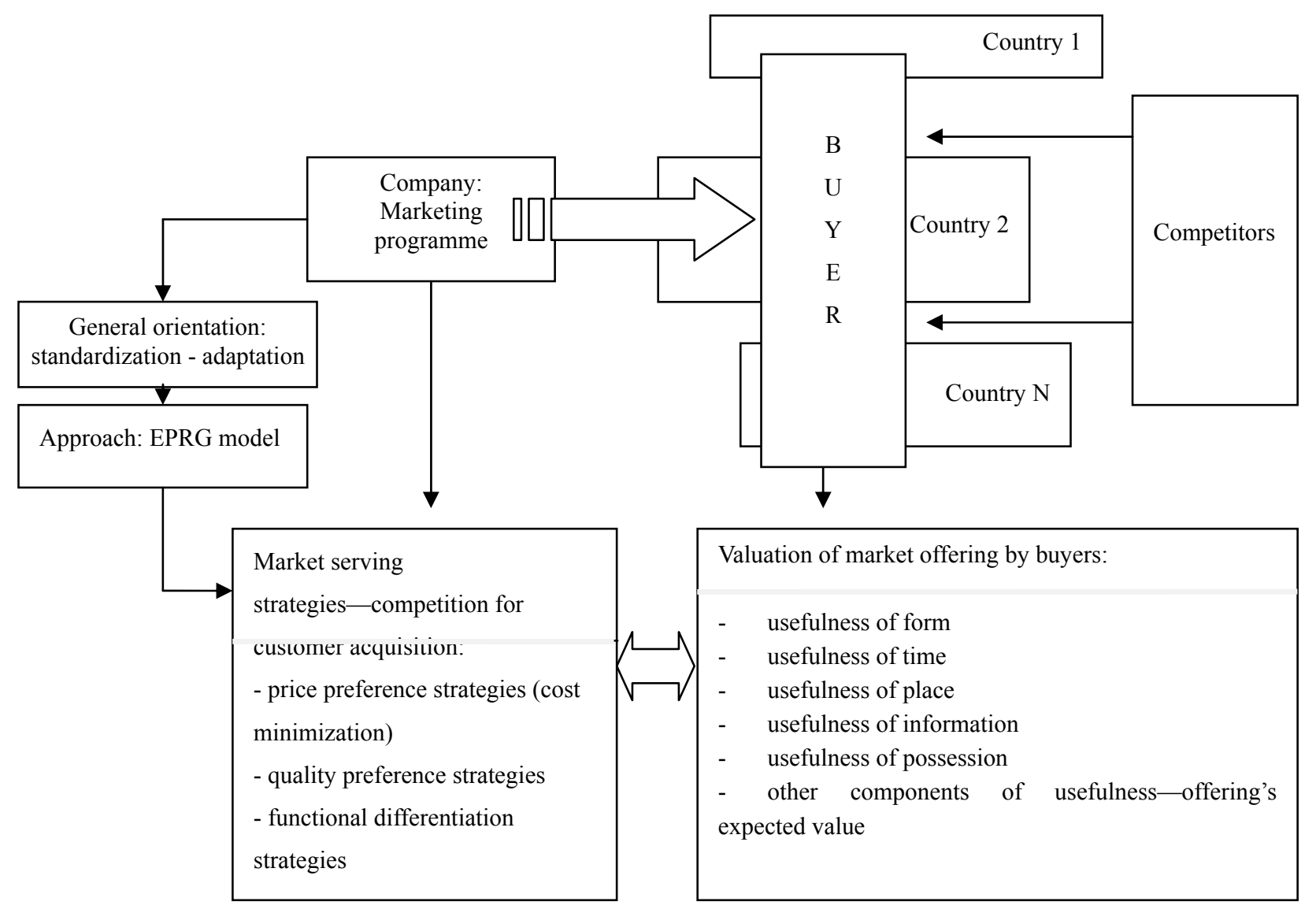

Figure 2. The model of strategies for serving international markets. Source: author's research.

The company's basic approach to an international market—-standardization and/or adaptation — is reflected in four specific strategies: ethnocentric (E), polycentric (P), regiocentric (R), and geocentric $(\mathrm{G})$. The ethnocentric and global approaches result from standardization, while the polycentric and regiocentric approaches are closer to adaptation.

The two dimensions of a business presence strategy on international markets (standardization/adaptation and EPRG model) are of key significance. In practice, they require more detailed description, and they should translate into specific strategies which identify the particular solutions and operating principles. They refer to the company's general functioning on the market as well as to its attitude to buyers, competitors, etc.. The particular strategic options, including the ones that refer to shaping the company's market space (Ansoff's matrix), operating principles in the specific stages of market development and the characteristics of functioning in different industries (depending on the scope and pace of globalization) are widely discussed in marketing and strategic management literatures, and they are not much differentiated when applied in the conditions of international markets. Importantly, all marketing strategies - those directed against competitors as well as those related to clients or agents - are based on the valuation of the market offering by prospective buyers. The market offering reflects all the significant components of the expected value including the usefulness of form, time, place, information, and possession. Customer expectations are referred to by all the marketing strategies, those related to the serving of the market as well as those which focus on the company's business presence on the market. A number of such strategies are discussed in detail in professional literatures (Porter, 1996; Proctor, 
1996; Pierścionek, 2003), for example, Wrzosek (2004) considers three factors: Demand and buyer preferences, the company's strength, and the character of the competitive environment, identify two types of strategic solutions:

- the company's participation in competitive processes;

- the choice of a strategy towards competitors.

The policy of avoiding competition is reflected in different modes of corporate integration and cooperation through joint ventures, mergers, and agreements on joint R\&D projects, etc.. On the other hand, the major strategies which have an impact on competitors are as follows:

- defensive strategies aimed to retain the present market position;

- pro-active (creative) strategies;

- passive strategies (adaptation strategies) - activities resulting from the passive adaptation to the market behaviour of competitors.

Corporate competitive strategies are divided by Porter (1996) into three different modes of operations: cost minimization and price leadership, the differentiation of offerings as compared with competitors' products, and a strategy of concentration.

Faulkner and Bowman (1996) had a different approach to competitive strategies. They claimed that market competition relies on two components: the customer's perceived value and the customer's perceived price. The company's effective market presence requires the activities aimed to increase product perceived value and to affect perceived price levels. This is a prerequisite for building a relatively lasting competitive advantage. This approach to competitive strategies plays a significant role in the context of company operations on international markets. It stresses different ways in which buyers in the particular countries and cultures perceive product value.

The analysis of rivalry and business presence strategies on international markets can be referred to Drucker's entrepreneurial strategies (2004). He discusses various modes of activities, describing them (in a controversial way) as "hitting them where they are not", "creative competition and creative imitation" and "entrepreneurial judo", finding and occupying "specialized ecological niche", as well as changes to the economic characteristics of the product, market or industry (Drucker, 2004).

Drucker's proposals may affect the company's decision as to the choice of its markets, entry strategies, and the order of internationalization stages as well as business presence strategies on international markets.

Business presence strategies on international markets can be referred to Ohmae's functional "differentiation strategies" (1982). They include four basic ways in which companies affect their markets:

- focus on key success factors;

- seeking to gain competitive advantage over weak competitors;

- aggressive initiatives;

- maximum customer satisfaction.

Each of these sub-strategies demonstrates an area for possible corporate activities on international markets. They refer to the major components of the strategy development process: customer needs and preferences, companies' resources and potential, and competitors' strengths on the market. The combination of the three strategic dimensions indicates not only the company's source of competitive advantage, but also the ways in 
which the company may impact its buyers and competitors. The strategies based on aggressive initiatives, creative imitation, and maximum customer satisfaction provide an opportunity for creating the company's positive image as compared with its competitors, constituting the major dimension of a strategy for the company's business presence on international and global markets.

The above considerations refer to the key aspects of corporate strategic decisions in international business. They cover two areas of issues: the company's entry modes and its business presence strategies on international markets. To a certain degree, such strategies may be regarded as controversial, but they seem to reflect the basic dimensions and aspects of the strategic decisions of international marketing, identifying the characteristics and attributes of companies' business presence on international markets.

\section{Conclusions}

The paper deals with the key aspects of corporate strategic decisions in international business. They cover two areas of issues: the company's entry modes and its business presence strategies on international markets. To a certain degree, such strategies may be regarded as controversial, but they seem to reflect the basic dimensions and aspects of the strategic decisions of international marketing, identifying the characteristics and attributes of companies' business presence on international and global markets.

\section{References}

Backhaus, K., Büschken, J., \& Voeth, M. (2001). Internationals marketing. Stuttgart: Schäffer-Poeschel Verlag.

Baláž, P. (2001). Medzinárodné podnikanie (International entrepreneurship). Bratislava: Jamex-Sprint vfra.

Ball, D. A., \& McCulloch, W. H. (1999). International business, introduction and essetials. Burr Ridge: Irwin.

Berekoven, L. (1985). International marketing. Berlin: Verlag Neue Wirtschafts-Briefe.

Bradley, F. (2005). International marketing strategy. Harlow: Pearson Education Ltd.

Cardona, P., \& Rey, C. (2009). Zarządzanie przez misję (Management through mission). Kraków: Oficyna Wydawnicza Wolters Kluwer.

Chlipała, P., \& Żbikowska, A. (2010). Eksport kooperacyjny a multiplikacja wartości w strategiach marketingowych przedsiębiorstw (Cooperation export and a multiplication of values in companies' marketing strategies). In A. Czubała, R. Niestrój, \& J. W. Wiktor (Eds.), Strategie marketingowe eksporterów (Marketing strategies of exporters). Kraków: Uniwersytet Ekonomiczny w Krakowie.

Czinkota, M. R., \& Ronkainen, I. A. (2004). International marketing. Mason: Thomson South-Western.

Czubała, A. (2012). Mission statements in the strategies of Polish lar gest exporters. In J. W. Wiktor, \& P. Chlipała (Eds.), The marketing strategies of Polish companies in international markets. Warsaw: Polish Economics Publishers.

Ďad’o, J. (1997). Medzinárodný marketing (International marketing). Banská Bystrica: ESOX Consulting.

Dietl, J. (2005), Ekspansja marketingu (The expansion of marketing). In J. W. Wiktor (Ed.), Euromarketing. Strategie przedsiębiorstw na rynku europejskim (Euromarketing: The strategies of companies on the European market). Kraków: Akademia Ekonomiczna w Krakowie (Cracow University of Economics).

Drucker, P. (2004). Natchnienie i fart czyli innowacja i przedsiębiorczość (Innovation and entrepreneurship. Pracice and principles). Warszawa: Wydawnictwo Studio Emka.

Duliniec, E. (2009). Marketing międzynarodowy (International marketing). Warszawa: Polish Economics Publishers.

Faulkner, D., \& Bowman, C. (1996). Strategie konkurencji (Competitive strategy). Warszawa: Wydawnictwo Gebethner \& Ska.

Fonfara, K. (2009). Zachowanie przedsiębiorstwa w procesie internacjonalizacji. Podejście sieciowe (The behaviour of a company in the process of internationalization. Network approach). Warszawa: Polish Economics Publishers.

Gorynia, M. (2007). Strategie zagranicznej ekspansji przedsiębiorstw (The strategies for international expansion of companies). Warszawa: Polish Economics Publishers.

Grzegorczyk, W. (2009). Marketing na rynku międzynarodowym (Marketing in international markets). Kraków: Wolters Kluwer. 
Harrison, A., Dalkiran, E., \& Elsey, E. (2000). International business: Global competition from a European perspective. New York: Oxford University Press.

Hermanns, A., \& Wissmeier, U. K. (1995). Internationals marketing management. München: Verlag Vahlens.

Hollensen, S. (2011). Global marketing: A decision-oriented approach. Harlow: Prentice Hall.

Hünerberg, R. (1994). Internationales Marketing (International marketing). Landsberg/Lech: Verlag moderne industrie (Publishing House Moderne Industrie).

Jaint, S. C. (2001). International marketing. Cincinnati: Thomson South-Western Learning.

Keegan, W. J., \& Green, M. C. (2011). Global marketing. Upper Saddle River: Pearson Education, Inc..

Kita, J. (2000). Marketing. Bratislava: Eknonómia.

Kotler, P. H., \& Keller, K. L. (2012). Marketing. Poznań: Rebis.

Kotler, P. H., Armstrong, G., Saunders, J., \& Wong, V. (2002). Marketing Podręcznik europejski (Principles of marketing). Warszawa: Polish Economics Publishers.

Kulhavy, E. (1990). Internationales marketing. Linz: Rudolf Trauner Verlag.

Lesáková, D. (2000). Globalisation and marketing strategy. In J. Ďad’o, \& J. W. Wiktor (Eds.), Marketing and globalization. Cracow: Cracow University of Economics.

Liberska, B. (2002). Mechanizmy i wyzwania (Globalization, mechanisms, and challenges). Warszawa: Polish Economics Publishers.

McGrew, A. G., \& Lewis, P. (1996). Granice konkurencji (The group of Lisbon. The limits of competition).Warszawa: Poltext.

Meissner, H. G. (1981). Aussenhandelmarketing. Stuttgart: Schäffer-Poeschel Verlag.

Mühlbacher, H. G., Dahringer, L., \& Leits, H. (1999). International marketing: A global perspective. London: ITBP.

Nowakowski, M. K. (2000). Biznes międzynarodowy—obszary decyzji strategicznych (International Business-the areas of strategic decisions). Warszawa: Wydawnictwo Key Test.

Nowakowski, M. K. (2008). Eurobiznes (Eurobusiness). Warszawa: SGH.

Obłój, K. (2002). Tworzywo skutecznych strategii strategii (The making of effective strategies). Warszawa: Polish Economics Publishers.

Obłój, K., \& Wąsowska, A. (2014). Zarządzanie międzynarodowe. Teoria i praktyka (International management. theory and practice). Warszawa: Polish Economics Publishers.

Ohmae, K. (1982). The mind of the strategist. New York: McGraw-Hill.

Pierścionek, Z. (2003). Strategie konkurencji i rozwoju przedsiębiorstwa (Competitive and developmental strategies). Warszawa: Polish Economics Publishers.

Porter, M. (1996). Strategia konkurencji. Metody analizy sektorów i konkurentów (Total global strategy. Managing for worldwide competitive advantage). Warszawa: Polish Economics Publishers.

Proctor, T. (1996). Marketing management. London: International Thomson Business Press.

Rymarczyk, J. (2004). Internacjonalizacja przedsiębiorstwa (Internationalization of a company). Warszawa: Polish Economics Publishers.

Schlegelmilch, B. B. (2001). Global marketing management: A European perspective. Harlow: Pearson Education Ltd.

Stabryła, A. (2000). Zarządzanie strategiczne w teorii i praktyce (Strategic management-Theory and practice). Warszawa: Polish Economics Publishers.

Stieglitz. J. E. (2011). Globalizacja (Globalization and its discontents). Warszawa: Polish Economics Publishers.

Stonehouse, G., Hamill, J., Campbell, D., \& Purdie, T. (2001). Globalizacja. Strategia i zarządzanie (Globalisation, strategy and management). Warszawa: Felberg SJA.

Sznajder, A. (1992). Strategie marketingowe na rynku międzynarodowym (Marketing strategies in international markets). Warszawa: Polish Economics Publishers.

Urbanowska-Sojkin, E., Banaszyk, P., \& Witczak, H. (2007). Zarządzanie strategiczne przedsiębiorstwem (Strategic management of a company). Warszawa: Polish Economics Publishers.

Wiktor, J. W., \& Chlipała, P. (2012). The marketing strategies of Polish companies in international markets. Warsaw: Polish Economics Publishers.

Wiktor, J. W., Oczkowska, R., \& Żbikowska, A. (2008). Marketing międzynarodowy. Zarys problematyki (International marketing: An overview). Warszawa: Polish Economics Publishers.

Wrzosek, W. (2004). Strategie marketingowe (Marketing Strategies). Warszawa: Polish Economics Publishers. 
Yip, G. S. (2004). Strategia globalna (Total global strategy II). Warszawa: Polish Economics Publishers.

Żabiński, L. (2002). Marketing globalny i jego strategie. Uwarunkowania, podstawowe opcje, instrumenty (Global marketing and its strategies. Determinants, basic options, instruments). Katowice: Akademia Ekonomiczna.

Żbikowska, A. (2012). Eksport jako forma internacjonalizacji polskich przedsiębiorstw. Uwarunkowania i strategie (Export as a form of internationalization of Polish companies. Determinants and strategies). Kraków: Polskie Towarzystwo Ekonomiczne.

Zorska, A. (2000). Ku globalizacji. Przemiany w korporacjach transnarodowych i w gospodarce światowej (Towards globalization: Transformations in transnational companies and in the world economy). Warszawa: PWN. 